\title{
KEBIASAAN MENCUCI TANGAN PADA ANAK SEKOLAH DENGAN KEJADIAN KECACINGAN DI DAERAH PESISIR DESA TADUI KECAMATAN MAMUJU
}

\author{
Rahmat Haji Saeni, Erdiawati Arief \\ Jurusan Gizi Poltekkes Kemenkes Mamuju
}

\begin{abstract}
The World Health Organization (WHO) in 2011 estimates that more than 2 billion people are infected with worms around the world, about 300 million suffer from severe worm infections and about 150,000 deaths occur annually due to STI (Soil transmitted helminths) infections. Deworming has a major impact on society because it affects intake, digestion, absorption and food metabolism. Cumulatively worm infections can cause nutritional loss of calories and proteins and blood loss that can cause anemia, inhibit physical development, mental, intellectual decline in children and work productivity, can decrease the body's resistance so easily affected by other diseases. The purpose of this study was to determine the relationship between hand washing habits and bathing habits with the incidence of worms. The research method used is cross sectional. The results of this study showed that there was a relationship between hand washing before eating and hand washing after to the occurrence of worm infestation with $p$ value of 0.02 and 0.04 respectively. The relationship of bathing habits also showed a statistical relationship with a $p$ value of 0.03 , whereas there was feces in the nails also showed a statistical relationship with a $\mathrm{p}$ value of 0.00 . Conducting efforts to promote clean and good living behavior both at school and community. Improve the promotion of handwashing, especially handwashing with soap.
\end{abstract}

Keywords: hand washing, bathing, worms

\section{PENDAHULUAN}

World health organization (WHO) pada tahun 2011 memperkirakan lebih dari 2 milyar orang terinfeksi cacing di seluruh dunia, sekitar 300 juta menderita infeksi cacing yang berat dan menurut Waris $\mathrm{N}$ dan Rahayu $\mathrm{N}$ tahun 2008 sekitar 150.000 kematian terjadi setiap tahun akibat infeksi STH (Soil transmitted helminths). Penyakit cacingan menimbulkan dampak yang besar pada masyarakat karena mempengaruhi pemasukan (intake), pencernaan (digestif), penyerapan (absorbsi) dan metabolisme makanan. Secara kumulatif infeksi cacing dapat menimbulkan kerugian zat gizi berupa kalori dan protein serta kehilangan darah yang dapat menyebab timbulnya anemia, menghambat perkembangan fisik, mental, kemunduran intelektual pada anak-anak dan produktifitas kerja, dapat menurunkan ketahanan tubuh sehingga mudah terkena penyakit lainnya (Kemenkes 2012).

Prevalensi Penyakit kecacingan di Indonesia diperkirakan sekitar $31.8 \%$ yang menyerang anak usia sekolah dan tersebar luas di pedesaan maupun di perkotaan (Kemenkes 2012). Hasil survei infeksi kecacingan di sekolah dasar (SD) di beberapa propinsi menunjukan prevalensi sekitar $60 \%-80 \%$, sedangkan untuk semua umur berkisar antara $40 \%-60 \%$ (Hairani, 2014). Hasil survei pada tahun 2012 dan 2013 pada 40 sekolah dasar pada 10 propinsi di Indonesia menunjukan prevalensi berkisar antara 2,2\% - 96,3\% (Sumolang, 2014). Selain itu, survey juga menunjukan prevalensi kecacingan ditemukan pada semua golongan umur, namun tertinggi pada usia anak SD yakni $90-100 \%$ (Marleta dkk., 2015).

Upaya yang dapa dilakukan dalam rangka meningkatkan derajat kesehatan baik di kelompok masyarakat maupun pada kelompok individu adalah dengan upaya promotif pada tingkat pelayanan kesehatan dan upaya preventi pada tingkat individu. Salah satu upaya yang dapat dilakukan adalah dengan berperilaku hidup bersi dan sehat (PHBS). Salah satu diantara indikator PHBS adalah mencuci tangan. Cuci tangan terkadang dianggap sesuatu yang biasa saja namun sesungguhnya dengan mencuci tangan dapat berkontribusi terhadap status kesehatan (Purwandari dkk. R, 2013).

Selain kebiasaan mencuci tangan, mandi juga merupakan salah satu upaya yang dapat dilkakukan untuk menjaga derajat 
kesehatan dan menjaga kebersihan seseorang Permasalahan mengenai kebersihan seringkali menjadi hal yang kurang diperhatikan akibat ketidaktahuan masyarakat maupun karena kebiasaan. Hasil observasi awal yang dilakukan di Desa Tadui menunjukkan adanya pola kebiasaan masyarakat, khususnya anak usia sekolah yang belum memenuhi syarat kesehatan.

\section{METODE PENELITIAN}

\section{Jenis Penelitian}

Jenis penelitian yaitu observasional analitik dengan menggunakan rancangan penelitian cross sectional study.

\section{Waktu dan Lokasi Penelitian}

Waktu pelaksanaan penelitian adalah pada bulan November tahun 2016, sedangkan lokasi penelitian adalah daerah pesisir Desa Tadui Kabupaten Mamuju.

\section{Populasi dan Sampel}

Populasi penelitian yaitu seluruh anak yang berusia antara 6 sampai 12 tahun dan bermukim di Desa Tadui, sedangkan sampel dalam penelitian ini adalah seluruh anak yang berusia 6 sampai 12 tahun dan bermukim di daerah pesisir Desa Tadui Kabupaten Mamuju. Jumlah sampel yang ada dalam penelitian ini adalah 91 sampel.

\section{Pengolahan dan Analisis Data \\ Pengumpulan data dilakukan dengan cara wawancara menggunakan kuesioner. Sedangkan pengolahan data dilakukan menggunakan sistem komputerisasi (Software Statistik). Analisis data yang digunakan dalam penelitian ini adalah analisis data univariat dan bivariat (Uji Chisquare) dengan nilai alfa sebesar 0.05 (CI 95\%).}

\section{HASIL PENELITIAN}

Berikut adalah hasil penelitian berdasarkan karakteristik responden yang terdiri dari jenis kelamin, umur (tahun) dan kelas, sebagai berikut:

\section{Tabel 1. Distribusi Karakteristik Responden berdasarkan Jenis Kelamin, Umur dan Kelas Anak Sekolah Dasar di Kawasan Pesisir Desa Tadui Kabupaten Mamuju Tahun 2016}

\begin{tabular}{ccc}
\hline Karekteristik Responden & Jumlah (n) & Persentase (\%) \\
\hline Jenis Kelamin & & \\
Laki - laki & 35 & 38.5 \\
Perempuan & 56 & 61.5 \\
Umur (Tahun) & & \\
7 & 10 & 11.0 \\
8 & 23 & 25.3 \\
9 & 32 & 35.2 \\
10 & 25 & 27.5 \\
11 & 1 & 1.1 \\
Kelas & & \\
2 & 19 & 20.9 \\
3 & 24 & 26.4 \\
4 & 21 & 23.1 \\
5 & 27 & 29.7 \\
\hline
\end{tabular}

Berdasarkan Tabel 1 di atas dapat diketahui bahwa jumlah responden berdasarkan jenis kelamin, perempuan lebih banyak dibandingkan dengan responden yang berjenis kelamin laki - laki yaitu sebesar $61.5 \%$, Selain itu, karakteristik responden yang terbanyak berdasarkan umur adalah responden yang berumur 9 tahun yaitu sebesar $35.3 \%$. dari table 1 di atas juga dapat diketahui karakteristik responden berdasarkan kelas yang terbanyak adalah responden yang duduk di kelas 5 yaitu sebesar $29.7 \%$. 
Tabel 2. Distribusi Hasil Pemeriksaan Laboratorium dan Jenis Cacing yang Menginfeksi Responden di Kawasan Pesisir Desa Tadui Kabupaten Mamuju Tahun 2016

\begin{tabular}{lcc}
\hline Pemeriksaan Laboratorium & Jumlah (n) & Persentase (\%) \\
\hline Terinfeksi Cacing & & \\
Ya & 67 & 73.6 \\
Tidak & 24 & 26.4 \\
Jenis Cacing & & \\
Askaris & 50 & 74.6 \\
Kremi & 16 & 23.9 \\
Askaris dan kremi $\quad$ Jumlah & 1 & 1.5 \\
$\quad$ & 91 & 100.00 \\
\hline
\end{tabular}

Berdasarkan Tabel 2 di atas dapat diketahui bahwa responden yang terinfeksi kecacingan sebanyak $73.6 \%$, sedangkan responden yang tidak terinfeksi cacing adalah sebanyak $26.4 \%$. Dari tabel di atas juga dapat diketahui bahwa jenis cacing yang paling banyak menginfeksi responden adalah jenis cacing Askaris yaitu sebanyak $74.6 \%$. Sedangkan jenis cacing kremi yang menginfeksi responden sebanyak 23.9 serta terdapat $1.5 \%$ responden terinfeksi oleh dua jenis cacing yaitu Ascaris dan Kremi.

Tabel 3. Kebersihan Tangan dan Kebiasaan Mandi terhadap Kecacingan pada Anak Daerah Pesisir Desa Tadui Kabupaten Mamuju Tahun 2016

\begin{tabular}{|c|c|c|c|c|c|c|c|}
\hline \multirow{3}{*}{ Variabel } & \multicolumn{6}{|c|}{ Infeksi Cacing } & \multirow{3}{*}{ P Value } \\
\hline & \multicolumn{2}{|c|}{ Positif } & \multicolumn{2}{|c|}{ Negatif } & \multicolumn{2}{|c|}{ Total } & \\
\hline & $\mathbf{n}$ & $\%$ & $\mathbf{n}$ & $\%$ & $\mathbf{n}$ & $\%$ & \\
\hline \multicolumn{8}{|l|}{$\begin{array}{l}\text { Kebiasaan Mencuci Tangan } \\
\text { Sebelum Makan }\end{array}$} \\
\hline Tidak Mencuci Tangan & 32 & 64.0 & 18 & 36.0 & 50 & 54.9 & \multirow{2}{*}{0.02} \\
\hline Mencuci Tangan & 35 & 85.4 & 6 & 14.6 & 41 & 45.1 & \\
\hline \multicolumn{8}{|l|}{ Kebiasaan Mencuci Tangan } \\
\hline Setelah BAB & & & & & & & \\
\hline Tidak Mencuci Tangan & 23 & 62.2 & 14 & 18.5 & 37 & 40.7 & \multirow{2}{*}{0.04} \\
\hline Mencuci Tangan & 44 & 81.5 & 10 & 37.8 & 54 & 59.3 & \\
\hline \multicolumn{8}{|l|}{ Kebiasaan Mandi } \\
\hline 1 Kali Sehari & 36 & 83.7 & 7 & 16.3 & 43 & 47.3 & \multirow{2}{*}{0.03} \\
\hline Lebih 1 Kali Sehari & 31 & 64.6 & 17 & 35.4 & 48 & 52.7 & \\
\hline \multicolumn{8}{|l|}{ Terdapat Kotoran dalam } \\
\hline Kuku & & & & & & & \\
\hline Ya & 43 & 86.0 & 7 & 14.0 & 50 & 54.9 & \multirow{2}{*}{0.00} \\
\hline Tidak & 24 & 58.5 & 17 & 41.5 & 41 & 45.1 & \\
\hline
\end{tabular}

Berdasarkan tabel 3 di atas dapat diketahui bahwa responden yang memiliki kebiasaan tidak mencuci tangan dan dan mengalami kecacingan sebesar $64.0 \%$, sedangkan responden yang memiliki kebiasaan mencuci tangan dan mengalami kecacingan sebesar $85.4 \%$. Nilai $\mathrm{p}$ value antara kebiasaan mencuci tangan sebelum makan dengan kejadian kecacingan sebesar 0.02 , sehingga secara statistik dapat dinyatakan ada hubungan diantara keduanya. Kemudian table 3 di atas juga menunjukkan bahwa responden yang memiliki kebiasaan tidak mencuci tangan setelah BAB dan mengalami kecacingan sebesar $62.2 \%$, sedangkan responden yang memiliki kebiasaan mencuci tangan setelah $\mathrm{BAB}$ dan mengalami kecacingan sebesar $81.5 \%$. Adapun $\mathrm{p}$ value antara kebiasaan mencuci tangan setealah $\mathrm{BAB}$ dengan kejadian kecacingan adalah 0.04 . 
Selain itu, dari tabel 3 di atas dapat diketahui bahwa responden yang memiliki kebiasaan mandi 1 kali sehari dan mengalami kecacingan sebesar $83.7 \%$ sedangkan responden yang memiliki kebiasaan mandi lebih dari 1 kali perhari dan mengalami kecacingan adalah sebesar $64.4 \%$. Adapun nilai $\mathrm{p}$ value hubungan antara kebiasaan mandi dengan kejadian kecacingan adalah 0.03 , dengan demikian ada hubungan sacara statisti diantara keduanya. Selanjutnya dari table 3 di atas dapat diketahu bahwa responden yang terdapat kotoran dalam kukunya dan menderita kecacingan sebesar $86.0 \%$, sedangakan responden yang tidak terdapat kotoran dalam kukunya dan mengalami kecacingan sebesar $58.5 \%$. Adapun nillai $\mathrm{p}$ value hubungan antara terdapat kotoran dalam kuku dengan kejadian kecacingan adalah 0.00. Dengan demikian dapat diketahui bahwa terdapat hubungan secara statistic antara terdapat kotoran dalam kuku dengan kejadian kecacingan

\section{PEMBAHASAN}

\section{Hubungan Kebiasaan Mencuci Tangan Sebelum Makan dengan Kecacingan}

Hasil penelitian menunjukkan adanya hubungan antara kebiasaan mencuci tangan dengan kejadian kecacingan. Penelitian ini tidak sejalan dengan penelitian yang dilakukan oleh Anwar dkk (2013). Hal ini dapat disebabkan adanya perbedaan perilaku cuci tangan.

Tangan adalah bagian tubuh kita yang paling banyak tercemar kotoran dan bibit penyakit. Ketika memegang sesuatu, dan berjabat tangan, tentu ada bibit penyakit yang melekat pada kulit tangan kita. Sehabis memegang pintu kamar kecil (sumber penyakit yang berasal dari tinja manusia), saat mengeringkan tangan dengan lap di dapur, memegang uang, lewat pegangan kursi kendaraan umum, gagang telepon umum, dan bagian-bagian di tempat umum, tangan hampir pasti tercemar bibit penyakit jenis apa saja. Kebiasaan mencuci tangan dengan sabun, adalah bagian dari perilaku hidup sehat. Cuci tangan dengan betul tidak hanya dipengaruhi oleh cara mencucinya, tetapi juga oleh air yang digunakan dan lap tangan yang digunakan (Purwandari, R dkk. 2013).

Kebiasaan mencuci tangan dengan sabun, adalah bagian dari perilaku hidup sehat yang merupakan salah satu dari tiga pilar pembangunan bidang kesehatan yakni perilaku hidup sehat, penciptaan lingkungan yang sehat serta penyediaan layanan kesehatan yang bermutu dan terjangkau oleh semua lapisan masyarakat. Perilaku hidup sehat yang sederhana seperti mencuci tangan dengan sabun merupakan salah satu cara untuk meningkatkan kesadaran masyarakat tentang pemeliharaan kesehatan pribadi dan pentingnya berperilaku hidup bersih dan sehat (Rabbi, E.S \& Dey, N.C. 2013).

Cuci tangan sering dianggap sebagai hal yang sepele di masyarakat, padahal cuci tangan bisa memberi kontribusi pada peningkatan status kesehatan masyarakat. Berdasarkan fenomena yang ada terlihat bahwa anak-anak usia sekolah mempunyai kebiasaan kurang memperhatikan perlunya cuci tangan dalam kehidupan sehari-hari, terutama ketika di lingkungan sekolah. Mereka biasanya langsung makan makanan yang mereka beli di sekitar sekolah tanpa cuci tangan terlebih dahulu, padahal sebelumnya mereka bermain-main. Perilaku tersebut tentunya berpengaruh dan dapat memberikan kontribusi dalam terjadinya penyakit infeksi pada usus. Cuci tangan merupakan tehnik dasar yang paling penting dalam pencegahan dan pengontrolan penularan infeksi dan dengan cuci tangan secara konsisten dapat mengurangi penyakit infeksi pada usus (Chittleborough, C.R. dkk. 2013).

\section{Hubungan Kebiasaan Cuci Tangan Setelah BAB dengan Kejadian Kecacingan}

Hasil penelitian menunjukkan adanya hubungan antara kebiasaan cuci tangan setelah $\mathrm{BAB}$ dengan kejadian kecacingan. Penelitian ini sejalan dengan penelitian yang dilakukan Mukono tahun 2015. Kebiasaan mencuci tangan setelah $\mathrm{BAB}$ dapat mempenagruhi penularan kecacingan melalui telur cacing yang terdapat pada faeses (Mukono dkk, 2015).

Kebiasaan anak yang paling sering dijumpai adalah memasuukan tangan kedalam mulut. Sadar atau tidak, ternyata hal ini sangat berdampak terhadap kesehatan anak, utamanya bagi anak yang tangannya terkontaminasi oleh agen penyebab penyakit. Hal ini seakan menjadi hal yang wajar dikalangan yang tidak tahu dengan perilaku yang berisiko, ditambah lagi dengan minimnya pengetahuan keluarga maupun kurangnya informasi yang didapat oleh anak (Martila dkk, 2015).

Kebiasaan mencuci tangan setelah bermain apalagi setelah buang air besar adalah hal yang seharusnya dirpmosikan dengan baik 
kepada setiap anak. Mengingat setiap kali seseorang yang telah melakukan buang air besar akan terpapar dengan tinja yang dikeluarkan. Namun tidak hanya cukup dengan cuci tangan saja akan tetapi juga diharapkan menggunkan sabun saat mencuci tangan (Chadijah, 2014).

\section{Hubungan Kebiasaan Mandi dengan Kejadian Kecacingan \\ Hasil penelitian ini menunjukkan} adanya hubungan antara kebiasaan mandi dengan kejadian kecacingan. Penelitian yang yang dilakukan oleh Nurul (2016) juga menunjukkan hal yang sama. Setiap orang akan memiliki pola kebersihan yang berbeda dan hal ini dapat berdapampak pada tingkat kebesihan seseorang. Pola kebersihan pada anak akan dipengaruhi oleh beberapa hal, diantaranya adalah pola asuh dan lingkungan keluarga ataupun lingkungan tempat tinggal. Anak yang telah terbiasa memiliki pola hidup bersih yang baik akan terbawah hingga dewasa bahkan hingga lanjut usia (Anwar 2016).

Salah satu penyakit infeksi yang dapat dipengaruhi oleh kebersihan perorangan adalah infeksi kecacingan, khususnya pada kelompok umur anak. Hal ini dapat disebabkan oleh tingkat kebersihan anak. Anak yang memiliki pola kebersihan yang kurang baik akan berisiko untuk terinfeksi kecacinga. Hal ini dapat disebabkan adanya agen penyrebab penyakit yang melengket pada kulit. Dengan demikian akan memudahkan agen tersebut untuk masuk kedalam tubuh malui tangan yang terkontaminasi dengan agen penyebab (Nurul, 2016).

Adanya agen penyebab penyakit yang melekat pada tubuh anak dapat dikendalikan dengan mejaga kebersihan. Diantara upaya tersebut adalah dengan menjaga kebersihan badan melalui upaya mandi minimal dua kali dalam sehari. Namun tidak hanya sekedar mandi akan tetapi pada saat mandi anak sebaiknya menggunakan sabun dan shampoo sebagai media untuk menghilangkan agem penyebab penyakit yang ada pada kulit (Desiyanto F A dan Djannah S N 2013).

\section{Hubungan Terdapat Kotoran dalam Kuku dengan Kejadian Kecacingan}

Hasil peneliti ini menunjukkan adanya hubungan antara terdapat kotoran dalam kuku dengan kejadian kecacingan. Penelitian ini tidak sejalan dengan penelitian Faridan dkk (2013).

Setiap anggota tubuh memiliki manfaat dan fungsi yang berbeda. Seperti mata untuk melihat, kaki untuk berjalan dan tangan untuk memegang. Diantara semua anggota tubuh, tangan merupakan bagian yang paling banyak melakukan aktifitas. Misalnya untuk kerja, mandi dan makan. Namun tidak sedikit orang yang tidak bisa menjaga kebersihan tangan dengan baik, utamanya kelompok anak-anak (Irman dkk, 2016).

Kebiasaan yang sering tidak disadari anak-anak adalah memasukkan tangan kedalam mulut tanpa melihat kondisi kebersihan tangan. Hal ini dapat memicu terjadinya infeksi penyakit kecacingan jika pada saat yang bersamaan di tangan terdapat kuman penyebab penyakit. Salah satu tempat yang strategis untuk kuman dingan adalah jika terdapat kuku yang panjang dan tidak terawat atau terdapatnya kotoran dalam kuku. Infeksi pada anak sering terjadi karena menelan tanah yang tercemar telur cacing atau melalui tangan yang terkontamisasi telur cacing (Rahmadhini dan Muthiara, 2015).

\section{UCAPAN TERIMA KASIH}

Terima kasih disampaikan kepada Direktur Poltekkes Kemenkes Mamuju yang telah memfasilitasi penelitian ini. Terima kasih juga disampaikan kepada seluruh responden serta semua pihak yang berkontribusi dalam penelitian ini.

\section{KESIMPULAN DAN SARAN}

Terdapat hubungan antara kebiasaan mencuci tangan sebelum makan kebiasaan cuci tanagn setelah $\mathrm{BAB}$, kebiasaan mandi dan terdapat kotoran dalam kuku dengan kejadian kecacingan pada anak daerah pesisir Di Kabpaten Mamuju.

Disarankan perlunya upaya promosi perilaku hidup bersih dan sehat baik di sekolah maupun di masyarakat. Meningkatkan promosi cuci tangan khususnya gerakan cuci tangan pakai sabun serta penyuluhan tentang pentingnya menjaga kebersihan lingkungan, khususnya pemanfaatan jamban yang ada.

\section{DAFTAR PUSTAKA}

Brown, H. W., (1983) dasar parasitologi klinik, Gramedia, Jakarta.

Basalamah, M. F., , F., Sam, U., M, B. F., Transmitted, S., \& Infections, H. (2013). 
Soil Transmitted Gmim Buha Manado. Hemoglobin, 1-6.

Bustan, M. N. (2006). Pengantar Epidemiologi. Edisi revisi. Rineka Cipta, Jakarta.

Chittleborough, C.R., Nicholson, A.L., Young, E., Bell, S \& Campbell, R. (2013). Implementation of an educational intervention improve hand washing in primary schools: process evaluation within a randomized controlled trial.BMC Public Health, 13:757, 2-11.

Departemen Kesehatan RI, (1998). Pedoman pemberantasan kecacingan, direktorat jenderal PPM \& PLP, Jakarta.

Departemen Kesehatan RI. (2004). Pedoman program nasional pemberantasan cacingan di era desentralisasi., Direktorat Jenderal Pemberantasan Penyakit Menular dan Penyehatan Lingkungan, Jakarta.

Departemen Kesehatan RI. (2006) Pedoman Pengendalian Cacingan. Jakarta.

F. Morton dan Richard. (2003). Epidemiologi dan Biostatistika. edisi 5. Penerbit buku kedokteran (EGC), Jakarta.

Fitri, J., Saam, Z., \& Hamidy, M. Y. (2012). Murid Sekolah Dasar Di Kecamatan Angkola Timur Kabupaten Tapanuli Selatan Tahun 2012. Jurnal Ilmu Lingkungan, 146-161.

Ghandahusada, Srissari; Herry; Illahude; Pribadi W. (2000). Parasitologi Kedokteran, edisi ketiga, 1998. Balai Penerbit FKUI, Jakarta.
Hadidjaya, P. (1994). Masalah Penyakit Kecacingan di Indonesia dan Penanggulangannya, majalah kedokteran Indonesia 44 (4), Jakarta.

Nasry Noor, Nur. Epidemiologi. (2008). edisi revisi. Rineka Cipta Jakarta.

Purwandari, R., Anisah Ardiana, \& Wantiyah. (2013). Hubungan antara perilaku mencuci tangan dengan insiden diare pada anak usia sekolah di kabupaten jember. Behaviour, 122-130.

Samosir, P., \& Medan, N. K. (2015). Pengaruh Derajat Infeksi Cacing terhadap Tingkat Kecerdasan Anak ( Case Study of students at SD Negeri 06777 Medan ). Jurnal IPTEK, 1, 7-12.

Santosa PN. (1994). Program UKS dan Peranannya dalam Penanggulangan Penyakit Kecacingan pada Anak Usia Sekolah Dasar, Laboratorium Farmakologi Klinik Fakultas Kedokteran Universitas Gadjah Mada, Jogjakarta.

Sorlie, D. E. (1995). Medical Biostatistics \& Epidemiology, Appleton \& Lange, First edition, East Norwalk.

Rabbi, E.S \& Dey, N.C. (2013). Exploring the gap between hand washing knowledge and practices in Bangladesh: a crosssectional comparative study. BMC Public Health, 13:89, 2-7.

World Health Organization. (2011). Soill Transmited Deseas, Geneva. 